\title{
Współczesne miasta Zagłębia Ruhry - zielone poprzemysłowe aglomeracje
}

\section{Contemporary Cities of the Ruhr- Green Post-industrial Agglomerations}

\begin{abstract}
Streszczenie
Zagłębie Ruhry przez dziesięciolecia było najbardziej zanieczyszczonym obszarem Niemiec. Pod koniec lat 80. XX wieku, kiedy zakończono produkcję w zakładach przemysłowych i zamknięto kopalnie rozpoczął się proces rewitalizacji w ramach IBA Emscher Park, który trwał do 1999r. Obecnie po prawie 20 latach po zakończeniu IBA można obserwować wieloletnie efekty działania całego procesu transformacji. Połączenie dziedzictwa kulturowego dawnych terenów przemysłowych naturalnym krajobrazem i nadanie im zupełnie nowych funkcji sprawia, że na obszarze zagłębia można zwiedzać wyjątkowe w swoim charakterze założenia, które stanowią główne atrakcje turystyczne całego regionu.
\end{abstract}

\begin{abstract}
The Ruhr was one of the most polluted areas in all of Germany for decades. Towards the end of the 1980's, when production ceased in industrial plants and mines were being closed down, a process of revitalisation began as a part of the IBA Emscher Park project, which lasted until 1999. At present, almost 20 years after the completion of the IBA, we can observe the longterm effects of the entire transformation process. The combination of the former industrial areas' cultural heritage with the natural landscape and assigning completely new functions to them has led to a situation in which we can visit complexes of outstanding character and that constitute the man tourist attractions of the entire region.
\end{abstract}

Słowa kluczowe: tereny poprzemysłowe, rewitalizacja, poprzemysłowy krajobraz miejski, środowisko na terenach rewitalizowanych Keywords: post-industrial areas, revitalisation, post-industrial urban landscape, environment in revitalised areas

\section{Wstęp}

W 2017 r. niemieckie miasto Essen zostało uzyskało tytuł Zielonej Stolicy Europy, który przyznawany jest co roku przez Komisję Europejską. Ten prestiżowy tytuł przyznawany jest ośrodkom miejskim, które wyróżniają się w zakresie poprawy jakości życia mieszkańców i dbałością o wysoką jakość środowiska naturalnego w myśl zasad zrównoważonego rozwoju. Przyznanie Essen tytułu ZieIonej Stolicy Europy jest szczególnym wydarzeniem, ponieważ jest to jedno z głównych miast Zagłębia Rurhy - największego niemieckiego okręgu przemysłowego. Zarówno Essen jak i okoliczne inne miasta przemysłowe takie jak Duisburg, Bochum, Gelsenkirchen itd., przeszły długą transformację od zanieczyszczonych ośrodków wydobycia i przemysłu ciężkiego po przyjazne mieszkańcom i środowisku miasta. Przekształcenia, które dokonały się na obszarze Zagłębia Ruhry obserwowane po prawie 30 latach od rozpoczęcia rewitalizacji w ramach IBA Emscher Park pokazują nowy krajobraz zagłębia. Jest to krajobraz intrygujący, który łączy zabytki techniki

\section{Introduction}

In 2017 the German city of Essen was awarded the title of European Green Capital, which is awarded every year by the European Union. This prestigious title is awarded to urban centres that stand out in terms of the improvement of the natural environment in accordance with the precepts of sustainable development. Awarding the title of European Green Capital to Essen is a particularly significant event, as it is one of the main cities of the Ruhr-Germany's largest industrial area. Both Essen and other neighbouring industrial cities such as Duisburg, Bochum, Gelsenkirchen, etc., have undergone a long transformation from being polluted centres of mining and heavy industry to cities that are friendly to their residents and the environment. The transformations that have taken place in the Ruhr and that have been observed for almost 30 years since the start of the revitalisation programme undertaken as a part of IBA Emscher Park project show the new landscape of the region. It is an intriguing landscape that combines 
z jej obsługą. Przez wszystkie lata ogromna kubatura i tereny huty staly sie dla mieszkanców miasta miejscem, z którym się utożsamiali, dlatego próby jej wyburzenia spotkały się z protestami lokalnej społeczności. ${ }^{3}$ Teren huty jest bardzo rozległy - to ok. 200 hektarów, na których znajduja się obiekty przemysłowe o różnej kubaturze, ale także otwarte niezagospodarowane tereny (na których gromadzono surowiec do wytopu żelaza) oraz założenia wodne. Program rewitalizacii huty umożliwi zaloźenia wodne. Príg zachow anie calosci za przemystowego. Park krajobrazowy, kowy powstat na cyną i za suzýc zám miesza atrakcje turystyczna Diusburg

wytopem żelaza - wielki piec i otaczające go budowle wznoszą się na wysokość kilkudziesięciu metrów ponad teren i dominuja w otaczającym je krajobrazie. Kształt obiektów jest wy jątkowy - ich forma zostala dostosowana do owczesne technologii wytopu zelaza lecz dzis kojarzy się z abstrakcyjnymi monumentalnymi rzezbami sztuki nowoczesne kosmicznymi obiektami lub nieznanymi dziwnymi skamieniałymi organizmami. Obiekty huty można zwiedzac - wyznaczono wokoł nich ścieżki edukacyjne, które pozwalają na zaznajomienie się z procesem wytopu żelaza. Na całym obszarze wokół pozostałości dawnego zakład przemysłowego rozciagają się tereny zielone. Ingerencja w przemysłową substancję jest różna - część miejsc jest pozostawiona przyrodzie, gdzie rodzina roślinnośc powoli zarasta poprzemysłowe tereny. W pozostałych częściach zaprojektowane są tereny zieleni urządzone bez naruszania struktury obiektów poprzemysłowych ogrody o różnorodnym charakterze w miejscach składowania żużlu, tereny rekreacyjne dla dzieci: place zabaw oraz wodny plac zabaw uruchamiany wo okresie letnim ścianki wspinaczkowe oraz miejse do nurkowania zorganizowane w dawnym zbiorniku gazu. Bogaty program funkcionalny proponowany w calym parku sprowia funkcjonalny proja to rodzin z dziećmi po profesjonalistów uprawiajacych nut kowane na duzych glebón jowa na duzo gebolosclach. Najwaznejsze jest jednak obcowanlew historią miejsca, bezposiednie spoglądanie na olbryy wio mury, miejsca wytopu zelaza, rożnorodne zbiorniki $i$ zasobniki itd. Usw Wadamia ogromn potęge przemyslu calego otoczenia. Pokazuje też, że historia miejsc się zmienia i ogromne zakłady przemysłowe równieź nie twają wiecznie, ale mogą zyskać nowe życie jednoczesnie zachowując dawną forme.

Kiedy powstawal program IBA Emscher Park władz miały przed sobą ogromne zadanie przewidziane $n$ lata i bardzo trudne do przeprowadzenia. Nie brakowało głosów o zasadności pozostawiania obiektów przemysłowych i nadawania im nowych funkcji. Obecnie z perspektywy lat widać, że zagłębie Ruhry stało się jedna z większych atrakcji turystycznych Niemiec. Opisane powyżej inwestycje rewitalizacyjne to jedne z wielu bardzo enormous massing of the metallurgy plant and its grounds became a place with which the city's residents identified themselves, which is why attemp to demolish it were met with protests from the local population ${ }^{3}$. The metallurgy plant grounds are quite large-they occupy around 200 ha of land, which is the site of industrial structures of varying size, as we as open, undeveloped land (on which raw materials used to smelt iron were stockpiled), as well as wate tion made. The programme of the plant's revitalisaits buildings and urban layout. The landscape park that has been built on its grounds has a function that is primarily focused on recreation and is mean to serve both residents and constitute Dusiburg's tourist attraction. Industrial structures associated with smelting iron-the main furnace and its surrounding structures, rise to a height of several doze metres above the ground and dominate in the surrounding landscape. The shape of the structures is exceptional-their form was adapted to the period's iron smelting technology, but today it brings to mind abstract monumental works of contemporary sculpture, cosmic structures or eerie unknown fossilised organisms. The structures of the metallurgy plan can be visited-education trails have been delineated around them, making it possible to familiarise oneself with the process of smelting iron. Green areas stretch along the entire area of the former industrial plant. The degree of intervention in industrial substance nature, with domestic plant life slowly overgrowing post-industrial aress In the remaining parts, are of landscaped greenery were designed without compromising the structure of the post-industrial areasgardens of varying character were placed on forme slag stockpiles, recreational areas for children: playgrounds and a water-themed playground open during summer months, climbing walls and a place for diving were organised in a former gas tank. The rich functional programme proposed in the entire park causes this place to attract various types of users: from families with children to deep diving professionals. However, it is experiencing the history of the place that is the most important-directly observing the enormous walls, iron smelting sites, various tanks and trays, etc., that demonstrates the immense power of the entire area's industry. It also shows that the history of a place can change and that enormous industral plants are not etennal either, but also that they When the IBA Emscher Park programme was being formulated the authorities had had an immense task ahead of them, one that was planned to be implemented over many years and very difficult to carry out. There was no shortage of questions as to the justification for leaving the industrial structures in place and assigning new forms of use to them. At present from a perspective of many years, we can see that the Ruhr has become one of Germany's greater tourist attractions. The revitalisation projects described above are some of many very interesting projects interesujących inwestycji służących obecnie mieszkancom oraz turystom. Inwestycje powstale w ramach procesów rewitalizacyjnych pokazuja, że można z sukcesem łączyć obiekty i tereny o zupełnie odmiennych funkcjach - kopalnię jako centrum kulturalne, hute jako park sportowo rekreacyjny itd., a wszystko to w otoczeniu zieleni i naturalnego krajobrazu. Jest to bardzo wyjatkowy sposób kształtowania współczesnych miast, gdzie priorytetem jest ochrona przyrody oraz tworzenie tereń́w zielonych, ale również zachowa kulturowego dziedzictwa przemysłowego.

PRZYPISY

Organizowanie projektów IBA (Miedzynarodowych Wystaw Budow-
nictwa) miato w Niemczech długą tradycie siegaiaca poczatków wieku. Projekty realizowano $w$ budynkach, dzielnicach i obszarach "Kusińska E. Woda w watożeniach architektoniczno - urbanistycznych",
Instytut Projektowania Urbanistycznego, Wydziat Architektury PolitechInstytut Projektowania Urbanistycznego,
niki Krakowskiej, Kraków 2009, str. 118

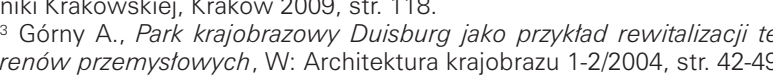

LITERATURA

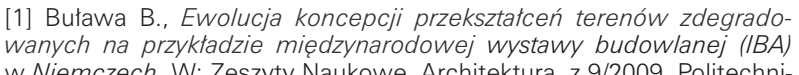

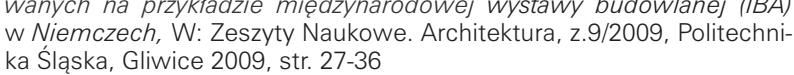
2] Wikosz-Mamcarczyk M. Rolaz aieleni w procesach rewitalizacij miast (w kontekscie zrównowaziones
nika Krakowska, Kraków 2015

[3] Early S.IDomagata K. Essen: Od przemystu do Zielonej Stolicy Euro01.2018 Af Pancewicz A., Środowisko przyrodnicze wo odnowie krajobrazu po-

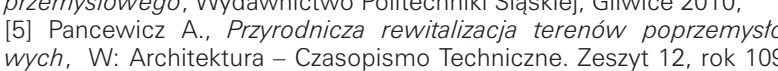
Wych, W: Architektura - Czasopismo Techniczne. Zeszyt 12, rok 109 ,
3-A/2012, s. $313-317$

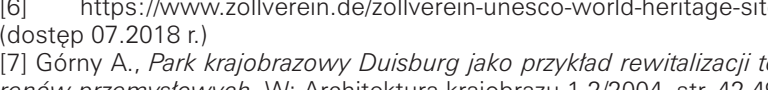

that currently serve both residents and tourists. Detion processes demonstrate that structures and areas with completely different functions can be successfully combined-a mine as a cultural centre and a metalurgy plant as a sports and recreation park, etc., all of it surrounded by greenery and the natural landscape. It is a highly unique manner of shaping contemporary cities, where protecting nature and establishing green is a priority.

ENDNOTES

1) The organisation of IBA projects (Internationale Bauausstellung
international architecture exhibition) had a longstanding tradition in Germany, dating back to the beginning of the twentieth century. The
projects were executed in buildings, courtyards and areas requiring Kusińska E. "Woda w zalozizniash. architektoniczno - urbanistycz-

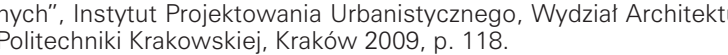
${ }^{3}$ Górny A., Park krajobrazony Duisburg jako przykład rewitalizaciji tere
nów przemystowych, in: Architektura krajobrazu 1-2/2004, p. 42-49

BIBLIOGRAPHY

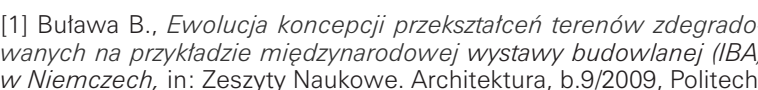
nika Ślaska, Gliwice 2009, p. $27-36$
[2] Wilkosz-Mamcarczyk M. Rola zieleni w procesach rewitalizaci

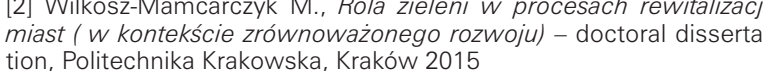
tion, Politechnika Krakowska, Kraków 2015
[3] Early S. Domagata K. Essen: Od przemystu do Zielonej Stolicy Europy, in: Deutsche
trieved on 01.2018$)$
[4l Pancewicz A.

Pancewicz A., Środowisko przyrodnicze w odnowie krajobraz wych, in: Architektura - Czasopismo Techniczne. Book 12,year 109 ,
3-A/2012, b. 313-317 6] https: / / w w w.zol

[7] Górny A., Park krajobrazowy Duisburg jako przyktad rewitalizacij te-
renów przemystowych, in: Architektura krajobrazu 1-2/2004, p. 42-49 